\title{
BOXED IN. CHALLENGES OF ESCAPING THE INHERITED SPATIAL REALITIES OF APARTHEID FROM THE CENTRE TO THE PERIPHERY
}

\author{
Tebogo Emmanuel Ramatlo
}

Tshwane University of Technology, Department of Architecture \& Industrial Design, Faculty of Engineering and the Built Environment, Tshwane, South Africa, ramatlote@tut.ac.za

\begin{abstract}
This paper interrogates the existing spatial realities of Johannesburg as it was shaped by colonialism and the challenges of providing an inclusive urbanism between the centre, the periphery and the in-between. Johannesburg is a major urban centre in South Africa, with increasing economic and spatial inequality. The inherited spatial realities are still evident today; these structural realities are restrictive, unsustainable, and disadvantage communities ecologically, economically and socially. The paper is premised on an understanding that economic inequality is related to spatial inequality.

The author draws on the personal lived experiences of being born on the periphery and the limitations of escaping the legacies of colonial spatial planning including the challenges of living on fragmented urban morphology.
\end{abstract}

The author looks at the typology of the segregated post-apartheid township and the negative elements of apartheids spatial planning, especially focused on the restrictions it has on housing, employment opportunities, transport and public space on the periphery in comparison to the centre and how the in-between spaces further perpetuate socio-economic disparity. The author attempts through research to understand the resilience adopted by the Soweto community to have a safe and welcoming place despite the persistence of structural restrictions. The intention is to address the fragmentation and segregation caused by the inherited spatial structures.

The planning of colonial cities, especially Johannesburg was based on achieving maximum control. The urban morphology was many times based on policies that organised people through race, class, and ethnicity.Its 
spatial planning was defined by separating citizens into different racial groups and economic classes. The rich white people located in the suburbs in the centre and the poor black people located in townships at the periphery separated by wide natural and man-made buffers in-between. The urban morphology of Johannesburg will be studied with a comparison analysis with other African cities which have similar patterns of spatial fragmentation in urban form due to colonial powers. The aim is to observe, compare and propose a defragmentation process towards the transformation of Johannesburg.

\section{Keywords: African cities, Johannesburg, spatial fragmentation, spatial defragmen- tation, inherited spatial realities.}

\section{RESUMEN}

En este artículo se analizan las realidades espaciales de Johannesburgo, tal y como fueron configuradas por el colonialismo, y los retos que plantea la creación de un urbanismo inclusivo entre el centro, la periferia y los espacios intermedios. Johannesburgo es un importante centro urbano de Sudáfrica, y del sur de África, con una creciente desigualdad económica y espacial. Las realidades espaciales heredadas siguen siendo evidentes hoy en día; estas realidades estructurales son restrictivas, insostenibles y perjudican a las comunidades ecológica, económica y socialmente. El documento parte de la premisa de que la desigualdad económica está relacionada con la desigualdad espacial.

El autor se basa en las experiencias personales vividas al haber nacido en la per- iferia y en las limitaciones para escapar de los legados de la planificación espacial colonial, incluidos los retos de vivir en una morfología urbana fragmentada. La autora examina la tipología del municipio segregado posterior al apartheid y los elementos negativos de la planificación espacial del apartheid, centrándose especialmente en las restricciones que impone a la vivienda, las oportunidades de empleo, el transporte y el espacio público en la periferia en comparación con el centro y cómo los espacios intermedios perpetúan aún más la disparidad socioeconómica. La autora intenta, a través de la investigación, comprender la capacidad de resistencia adoptada por la comunidad de Soweto para disponer de un lugar seguro y acogedor a pesar de la persistencia de las restricciones estructurales. La intención es abordar la fragmentación y la segregación causadas por las estructuras espaciales heredadas.

La planificación de las ciudades coloniales, especialmente de Johannesburgo, se basaba en lograr el máximo control. La morfología urbana se basaba muchas veces en políticas que organizaban a las personas por raza, clase y etnia.Su planificación espacial se definía separando a los ciudadanos en diferentes grupos raciales y clases económicas. Los blancos ricos se situaban en los suburbios, en el centro, y los negros pobres, en los municipios, en la periferia, separados por amplios márgenes naturales y artificiales. La morfología urbana de Johannesburgo se estudiará con un análisis comparativo con otras ciudades africanas que tienen patrones similares de fragmentación espacial en la forma urbana debido a los poderes coloniales. El objetivo es observar, comparar y proponer un proceso de desfragmentación hacia la transformación de Johannesburgo. 
Palabras clave: Ciudades africanas, Johannesburgo, fragmentación espacial, desfragmentación espacial, realidades espaciales heredadas.

\section{RESUMO}

Este documento interroga as realidades espaciais existentes em Joanesburgo, moldadas pelo colonialismo e os desafios de proporcionar um urbanismo inclusivo entre o centro, a periferia e o meio. Joanesburgo é um importante centro urbano na África do Sul, e na África Austral, com crescente desigualdade econômica e espacial. As realidades espaciais herdadas são ainda hoje evidentes, realidades estruturais estas restritivas e insustentáveis, que prejudicam as comunidades ecológica, econômica e socialmente. $\mathrm{O}$ artigo fundamenta-se no argumento que a desigualdade econômica está relacionada à desigualdade espacial.

O autor, nascido na periferia de Joanesburgo, baseia-se em suas experiências pessoais de vida e nas limitações de escapar aos legados do planejamento espacial colonial, incluídos os desafios de viver em uma morfologia urbana fragmentada. O autor examina a tipologia de cidade segregada pós-apartheid e os elementos negativos do planejamento espacial do apartheid, em particular nas restrições à moradia, oportunidades de emprego, transporte e espaço público na periferia, em comparação com o centro e como os espaços intermediários perpetuam ainda mais a disparidade socioeconômica. Por meio da pesquisa, o autor almeja melhor compreender a resiliência da comunidade de Soweto para a construção de um lugar seguro e acolhedor, apesar da persistência de restrições estruturais. O objetivo é investigar a fragmentação e a segregação causadas pelas estruturas espaciais herdadas.

O planejamento das cidades coloniais, especialmente Joanesburgo, foi baseado na obtenção do máximo controle. A morfologia urbana foi muitas vezes decorrente de políticas que organizavam as pessoas pela raça, classe e etnia, sendo o planejamento espacial definido pela separação dos cidadãos em diferentes grupos raciais e classes econômicas. Os brancos ricos localizados nos subúrbios do centro e os negros pobres localizados em bairros da periferia, separados por amplos amortecedores intermediários naturais e artificiais. A morfologia urbana de Joanesburgo será estudada por meio da análise comparativa com outras cidades africanas, de padrões semelhantes de fragmentação espacial da forma urbana devido aos poderes coloniais. O objetivo é observar, comparar e propor um processo de desfragmentação em direção à transformação de Joanesburgo.

Palavras-chave: Cidades africanas, Joanesburgo, fragmentação espacial, desfragmentação espacial, realidades espaciais herdadas.

\section{INTRODUCTION}

In South Africa during Apartheid, every major city and minor town received a lesser twin the township- built to house non-white South Africans. The townships were an integral part of the state's strategy to keep black and nonwhite South Africans in a disadvantaged position. Part of Apartheids tools were to limit accessibility of the natives or non-white popu- 
lation from city centres and displace them from their homelands and city centres to locations on the peripheries. The urban morphology of the city was engineered to separate, dislocate and fragment neighbourhoods into racial zones that feed the inner core/city centres especially in the case of Johannesburg. According to Demisse (2012:21) from its inception, colonialism pervaded all aspects of the built environment by forcibly removing native populations to racial and highly policed zones outside the city known as native locations or native towns which have issues with congestion, overcrowding and exploitation. The spatial limitations, physical barriers, narrow nodes and dormitory townships are remnants of apartheid planning and mining sector.

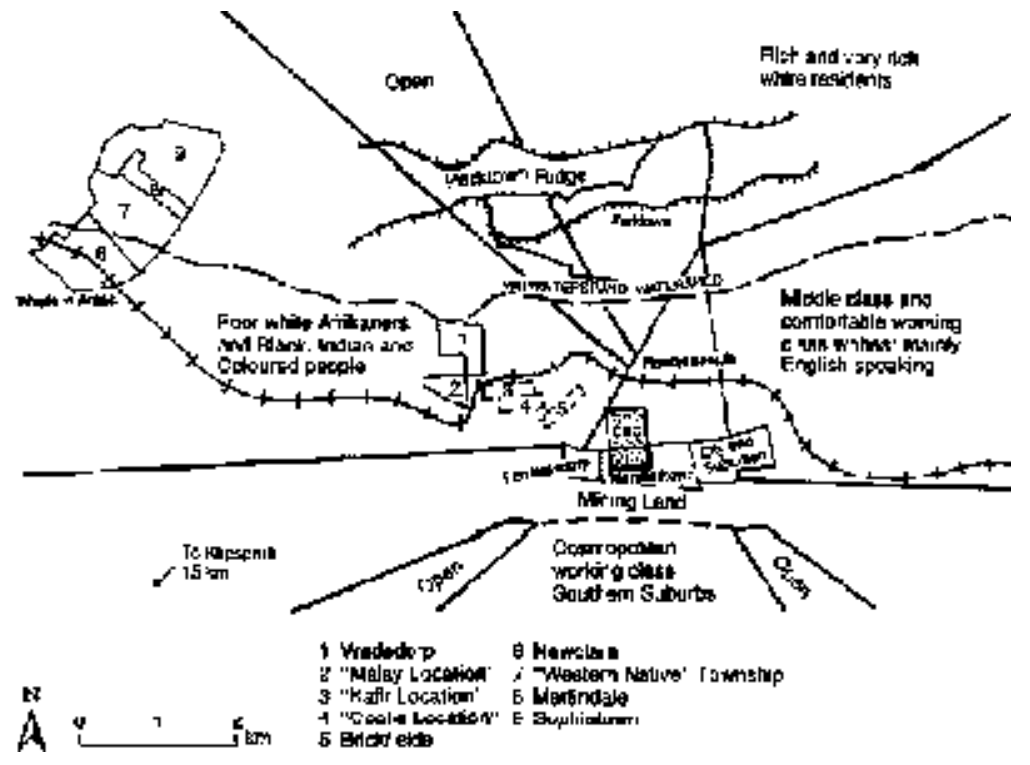

of Soweto have, and still do, face challenges towards accessing of adequate housing, economic development and social and spatial isolation and disconnection from the rest of the city.This fragmentation manifests differently in different parts of the city: the centre, the in-between and the periphery.Townships were rolled out as dormitory towns of non-white South Africans as the means to provide cheap labour for the city centre and neighbouring suburbs. The spatial planning of townships and its housing typology are one of the most visible and notorious remnants of the Apartheid era. The township houses informally known as matchbox were referred to as NE51/9 (nonEuropean housing designed in 1951, version 9). The matchbox was the basic building block, minimal dwelling divided into four rooms, repeated with little variation, on cheap land and at a distance to centres of employment, services and business. The small size and scale of the township houses meant limited personal space and a lack of privacy, which meant that children and adults alike spent much of their time in the streets. Morphet (1998:159) writes: "South Africa under the pressure of apartheid lost the positive meanings of both moder-
Fig. 1.1 Johannesburg Spatial Segregation(archive.unu. edu, 2019)

For people living in Soweto (short for South Western Township) far from the city centre as and still is, frustrating. The residents nism and regionalism. The designs and techniques of the international styles were put to work to fragment the population into culturally insulated locations and 'homes' from which they could not escape". 


\section{PEOPLE MOVE, BUILDINGS STAY, IDEAS LIVE FOREVER}

Two decades into its democracy, Johannesburg like other major cities in South Africa still struggle to integrate along its racial and economic lines because of the inherited spatial morphologies shaped by colonial planning and policies. This structural resilience of apartheid still to this day affects and limits the ability to provide inclusive, safe, resilient and sustainable human settlement. The gold rush reinforced by land seizures and laws on natives instituted forced migrations. The culture of migration is still prevalent to this day. This chapter addresses the change of political institutions and its effects on previously segregated communities. The move from apartheid to democracy saw a significant increase in urban migration. Neighbourhoods like Hillbrow in the city centre of Johannesburg were already transforming from an isolated rich white community into a racially inclusive metropolitan centre during the dawn of democracy. For some, it was a time to integrate and move past the colonial scars yet for some it threatened their wealth and wellbeing. The majority fled from the city centre into gated communities, which reflects the insecurities and schizophrenia of white minority rule.

This study is based on the worldview that socio-economic equity has not been achieved, and this remains as a challenge in city locations, which emerged because of historical realities, policies, and practices that have created spatial fragmentation and divisions. Spatial fragmentation is one of the major causes of economic inequality, social exclusion and increase in unemployment; which leads to higher poverty levels, conflicts and backlog in public
services.The lived experiences of communities between the centre and the periphery vary dramatically and their participation is influenced by their socio-economic standpoint. Their lack of accessibility to better educational, social and economic nodes is directly linked to their spatial restrictions. One may define the term community in fragmented society as individuals of shared interest. Individuals protect their shared interest depending on their collective socio economic standpoint. "Not only does the psychological effect of being poor while having rich neighbours harm the health and well-being of low income residents, but when inequality is visible to the naked eye, the affluent individuals are less likely to support the distribution of wealth" (Sands, 2017).

The practice of segregation continued as a concept and disguise by means of new developments. From colonialism until now the pattern and practice of spatial segregation persists. The repetition of fragmentation continues through means of decentralisation as both a concept and means for new development. New central business districts (CBD) are formed outside of the urban core to protect and attract private investment. Johannesburg in the 1980 s formed Sandton as an alternative CBD over the old CBD because of the increased insecurities of the apartheid government due to the growing political crisis of the time (Chipkin, 2008:159). Sandton's development is aimed at attracting private investments and a wealthy social class. The urban form is socially exclusive, restrictive and hostile. Most office buildings are raised of the public sidewalk to discourage any public physical and visual interaction between the pedestrian and building. The rapid urbanisation has a direct effect on the sustainability of the 


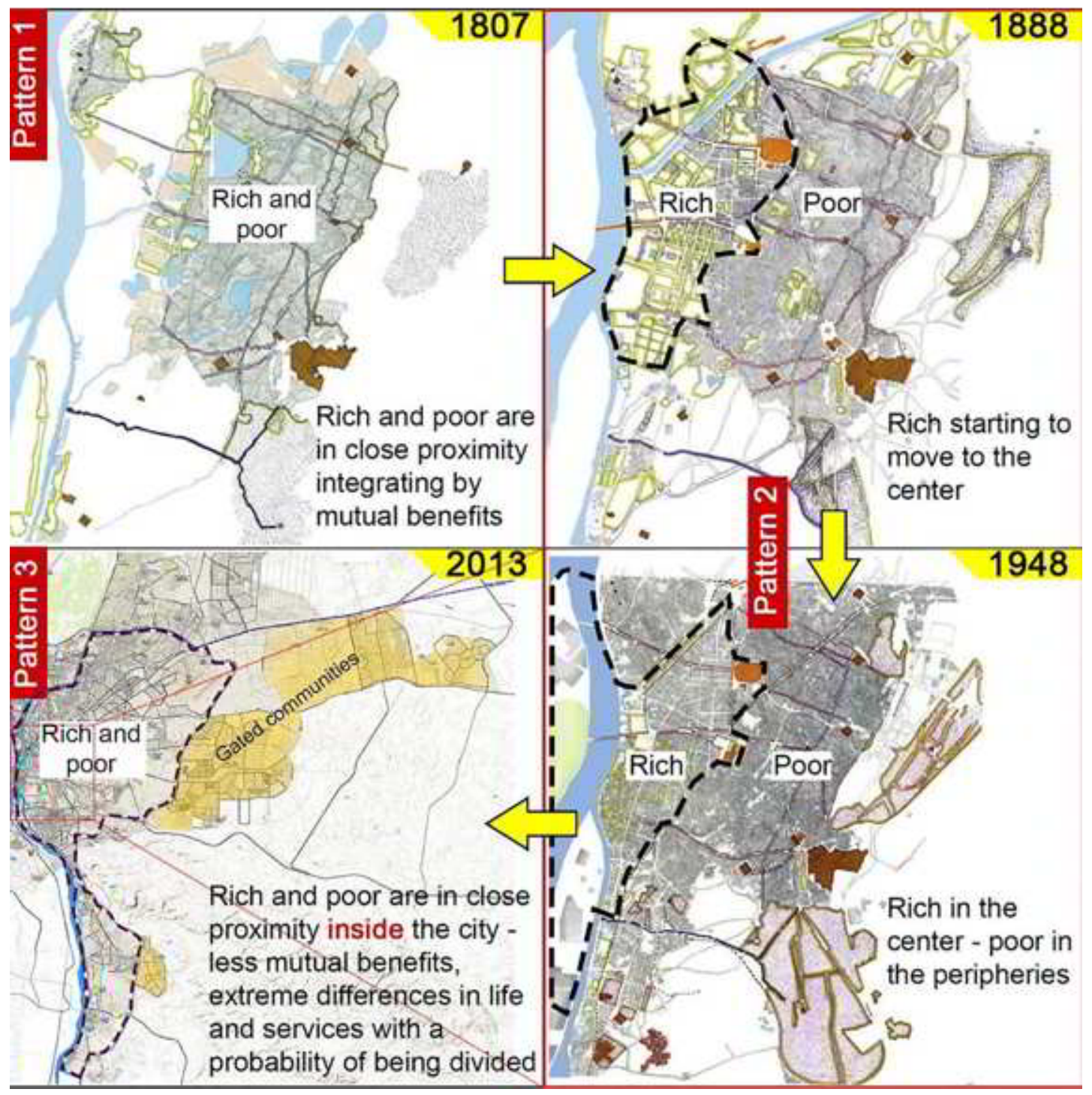

Fig. 1.2 Historical spatial segregation in Cairo. Aya Badawy, Hassan Abdel-Salam and Hany Ayad. News24, 2018.

urban development. The expansion of previously colonial cities is largely informal than formal. Angel (2018:21) states that "We suspect that most urban planners and policymakers -at the local, national and international level- are not fully aware of the extent to which urban peripheries are growing and are unsure of the quality of the urban fabric in these new urban peripheries". Despite the fact that this development trend addresses the current needs of 
mass population's accessibility towards housing and employment opportunities, it also normalises the trend of informal economic, housing and transport mobility development. The normalisation of informality ignores the problem at hand. These development trend increases inequality between dwellers in the centre and the periphery. Moreno (2018:19) states that "although urbanisation is not uniform, the experiences of diverse cities around the world exhibit some remarkable similarities. Cities are generally de-

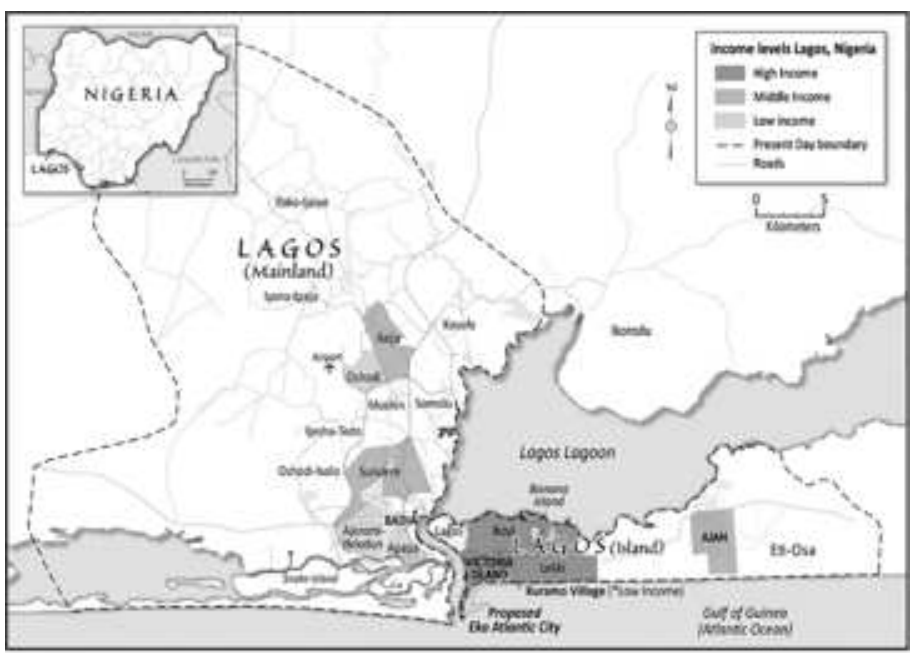

Figure 1.3 Lagos Spatial Segregation. Research Gate Net (Idowu Ajibade 2013)

urban laws. The way New Cairo developed was unfortunately the contrast of all-inclusive urbanism. It actually represents a setup for another process of social exclusion, due to several reasons: the appearance of walled gated communities, whether residential, business, educational or commercial, which eventually led to urban fragmentation.

Like Johannesburg in the 70s, Lagos began planning New City in the centre of the country called Abuja. The attempt was to escape the problems of the capital city Lagos with a new well established city to cope with the increasing populations. According to Obiadi and Nzewi (2018:1124) the Abuja Master plan was elaborated to put in place a sustainable urban spatial environment for all ethnic groups and economic classes which in turn failed due to negligence in urban development and adequate accommodation. The negligence forced the most vulnerable urban poor to arrange their own place to live closer to work 
place in order to reduce transportation and rent incidence on their income and that resulted in shanty settlements in both formal and informal housing areas. Today Lagos is conceiving another multi-billion developments on its shores called Eco Atlantic City. According to the African Development Bank Group (2018:5) the space within the central areas of Lagos is heavily restricted and in response to the need for land and for future development and the necessity for a long-term solution to the erosion problems of Victoria Island, South Energyx Development F.Z.E (SEDFZE) developed the proposal for the Eko Atlantic Development Project (EAD). Although there is great shortage of adequate housing and majority of the population in Lagos living in poverty the Eko Atlantic Development (EAD) project caters housing for middle and high class. Watson (2013:216) argues that "these new urban visions and development plans appear to disregard the fact that at the moment, the bulk of the population in sub-Saharan Africa cities is extremely poor and living in informal settlements. Some of these settlements are on well-located urban land that is also attractive to property developers. Attempts to implement these fantasy plans within existing cities will (and is already) having major exclusionary effects on vulnerable low-income groups through evictions and relocations. Moreover, these development interests bring with them a host of additional demands -for new and particular forms- of urban infrastructure and for forms of governance and decision-making that facilitate the realization of property investment interests".

Moreno (2018:19) argues that "Despite the opportunities urbanisation represents, many cities today fail to make sustainable space for all, not just physically, but also in the civic, socio-economic and cultural dimensions attached to collective space. Growing inequality, social exclusion and spatial segregation continue to have an impact on people's lives in most of the world's cities". The effects of poor planning, divided landscapes and unsustainability of cities can be traced back to colonial times. Baruah, Henderson, and Peng (2017) state that "the persistence of institutions from colonial times may explain the development patterns of many African cities today. Former British colonial cities appear more fragmented than former French colonies; their development has been patchier, more scattered and strung out, with more open space".

\section{NEW URBAN PERIPHERIES}

The advent of democracy saw a wide range developments mostly aimed at addressing challenges towards housing and employment. The rapid house development is a continuation of the same matchbox township model. It is referred to as NE51/9 (non-European housing designed in 1951, version 9). This spatial planning redefines the edges of the periphery. The planning is strung-out and it increases travel distance including cost for the already marginal community. Prime land next to the city centre was sold for private developments such for the middle, upper middle and middle class. These developments occurred in a gated community format and private estates. However different both developments were in terms of target market, their physical appearance in the landscape worked on a similar ideology of sameness. The rollout of housing typology worked on a template of repetition. This repetition happened at 
a rapid rate that most of open -accessible land got used up thus forcing both private developments and RDP housing to the far peripheries.

In an attempt to escape the rubbing between the poor and the rich, private developments created new housing enclaves with private health, retail, educational and recreational amenities. The walled in estates turn a blind eye on the reality of increasing inequality. There persistence and existence of such structures and fragmented spatial planning puts a strain on the existing under development municipal state services such as water and electricity. It stretches travel time and distance to the extreme and limits accessibility to efficient public transport. Lall et al (2017) state that: "With cities physically dispersed, Africans in urban areas are disconnected from one another. Urban expansion has occurred as leapfrog patches - small parcels of newly built land that do not border, intersect or overlap on existing urban built up areas, leading to high transportation cost and lower access to markets and other people in the city. Within the urban core, population's densities vary widely across locations, reducing the chances for the large sections of the population to interact with other groups in the city".

The paper argues that fragmented development often creates a huge strain on the states resources and services. The poor lack of service and management has been a problem since colonial times to date especially to the marginalised communities. The newly built urban expansions whether informal or formal still to this day rely on the poorly serviced roads, power stations, health facilities, water connections and all other state institutions. This disenfranchisement often breeds a pri- vate institutional development from housing to health, which is expensive and accessible by the selected few. Gated communities, private schools, medical centres are among many of the private developments which ignore the reality of the separation and socio-economic exclusion. The current global pandemic (Covid-19) also reveals the effects of poor urban planning and inherited spatial realities of colonialism. Living in small, restrictive, and dense spaces promote the spread of respiratory diseases. Social distancing becomes a real challenge to communities living in informal, small, dense dwelling than communities living in suburbs with better health care. "Urban development is regulated through zoning and land use laws. This may appear to be a neutral construct but it is not: "Urban-social policies are constituted in manifold ways, through language and concepts, institutional frameworks, agencies of delivery and the experiences of people on the "receiving end" of such policies". (Haylett, 2003:56)

The success of divided cities has often relied on the natural and or man structures that form physical barriers between different communities. Soweto being the only township close to Johannesburg city centre, apartheids spatial planners further reinforced its segregation to it by building huge mine dumps in-between. The physical barriers were generated from the underground waste of the mines. Still to this day the mine dumps act as barrier to limit accessibility and visually block the township from the centre. Demissie (2012:3) maintains that: "A system of boundaries (cordon sanitaire) and its supporting architecture was developed to reinforce the separation of the European towns from the "native towns". Thus, walls, buffer zones and defensive architecture 
were incorporated in the planning of colonial cities as part of a wider spatial strategy to ensure surveillance and control over the African populations". The layout of the barriers limits the transport mobility and control accessibility to the core. With the travel, distance stretched out which directly affects costs, the majority of the township residents are forced to use under maintained railway system. In attempts to provide increase public transport services, the post-apartheid government introduced BRT bus transit system called the Rea Vaya as an alternative to the deteriorating train system. The Rea Vaya bus transit is a part of citywide project called corridors of freedom. Even though the project aims to increase accessibility and efficiency in transportation, its does the opposite. It is expensive, inaccessible and further perpetuates the culture of marginalisation and using black bodies as work force for the inner city. The community in frustration has destroyed majority of the infrastructure and looted its remains as it doesn't answer its primary concerns of poverty, unemployment and service delivery.

\section{BENEFITS OF DEFRAGMENTATION}

Africa has the potential to be a leading example of inclusive urbanism where all are diverse communities are equal. The paper aligns itself with the United Nations sustainable development goal 11 of the 2018 report. The goal aims at making cities and human settlement inclusive, safe resilient and sustainable. The goal focuses around managing rapid urbanisation and providing infrastructure to support growing populations by 2030. According to UN projections Africa will more than double is urban population over the next two decades, from 400 million presently to a staggering 750 million in 2030 and 1.2billion by 2050. "The rapidity and scale of this demographic and social transition is almost unimaginable especially if

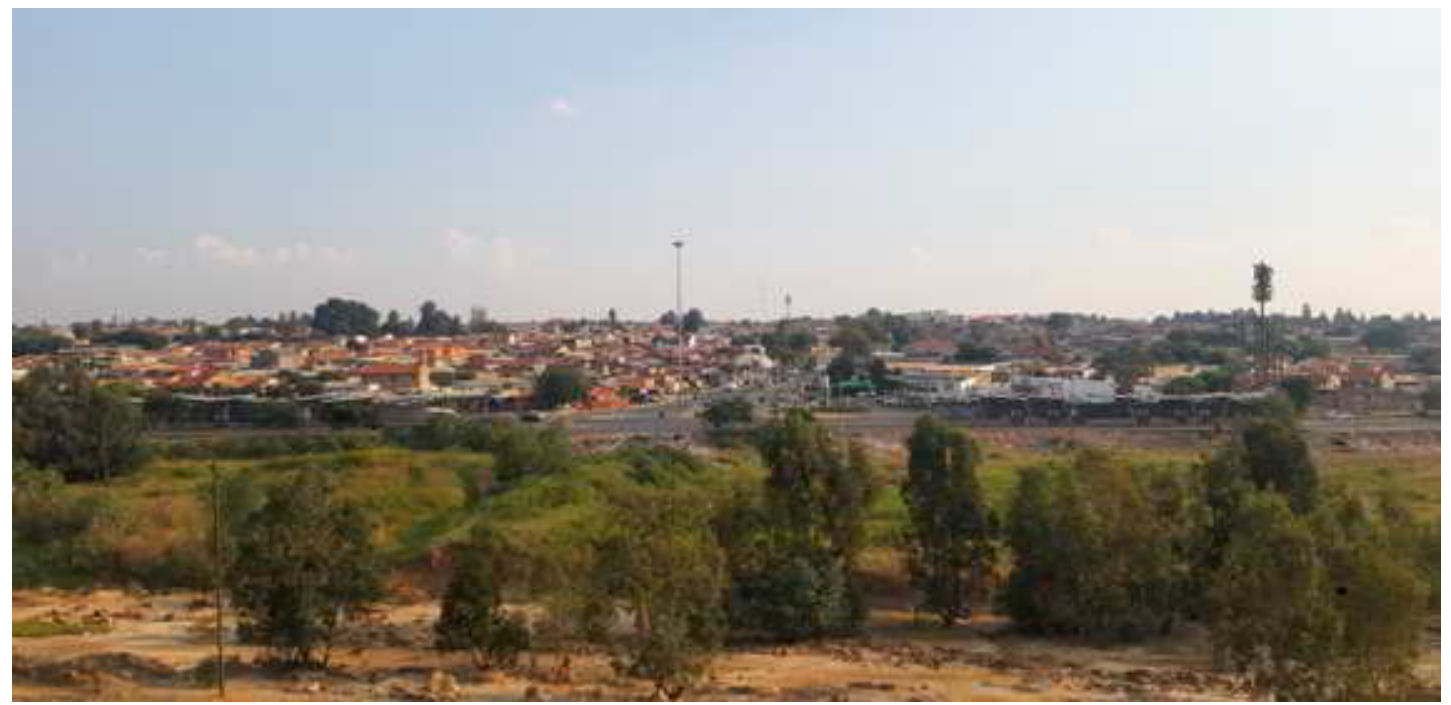

Fig. 2. View of Diepkloof from the mine dump used as physical barrier for Soweto from Johannesburg (author, 2021) 
one considers that the vast majority of existing urbanites make do in utterly miserable living conditions due in part to state neglect, skewed economic development patterns, limited resources and administrative incompetence; dynamics that are of course in one way or another tangible legacies of the savage colonial experiment we have been subjected to for most of the enlightenment." Pieterse 2009:1)

Inclusive, safe, sustainable living is not just for urban the poor but it is also a platform for reducing if not eradicating a persistent state of crisis. State of crisis relates to the constant need for humanitarian support to eradicate poverty, diseases and unemployment. The environment leaves the inhabitants in state of urban limbo. Urban limbo refers to a position where an individual has mixed feelings of belonging and un-belonging. The place creates anxiety and feeling of wanting to escape. The current urban context does not reflect the needs of the many, most of which are living on the margins far from a better life, economic nodes and better public services. Sustainable inclusive environments are the prevention not the cure to urban form. It talks to a healthy society where preventative methods are in place to avoid foreseeable and unforeseeable effects of exclusivity. It talks to an environment where your ability to be socio-economically emancipated is not affected by your position, distance and scale from the economic center. It is urban environment where the state services can cope with the ever changing needs of the society and the urban environment. This study is based on the world view that socio-economic equality and or equity has not been achieved, and this remains a challenge which emerged because of historical realities, policies and practices that have created spatial fragmentation and divisions. The study is based on a premise that:

Historical realities of African cities and spatial implications, can be changed by bridging the fragments spatially for an increased economic equity, access to affordable housing, public space and employment opportunities. Current researchers define three aspects of connected urban morphology.

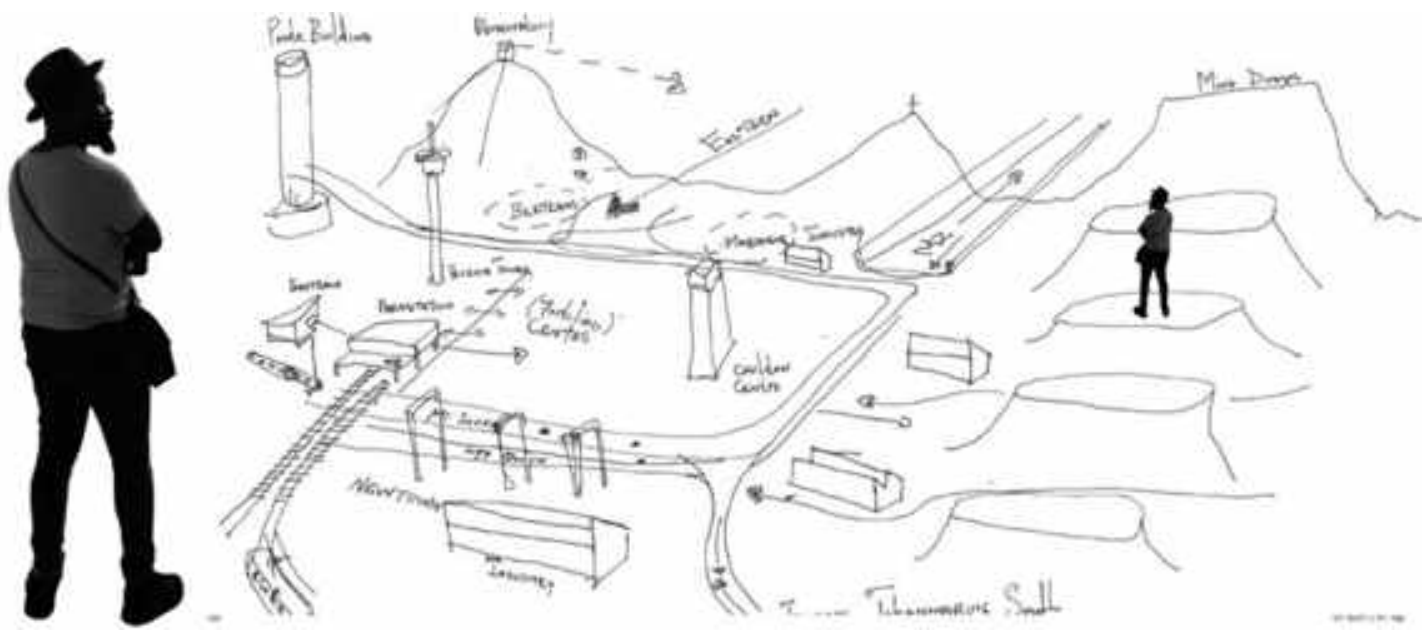

Fig. 3. Analysis of Johannesburg (author 2021) 
The Centre: (the CBD, suburbs, industrial node), the In-between: (the thresholds, buffers, gateways, mobility) and the Periphery: (the locations, the residence)

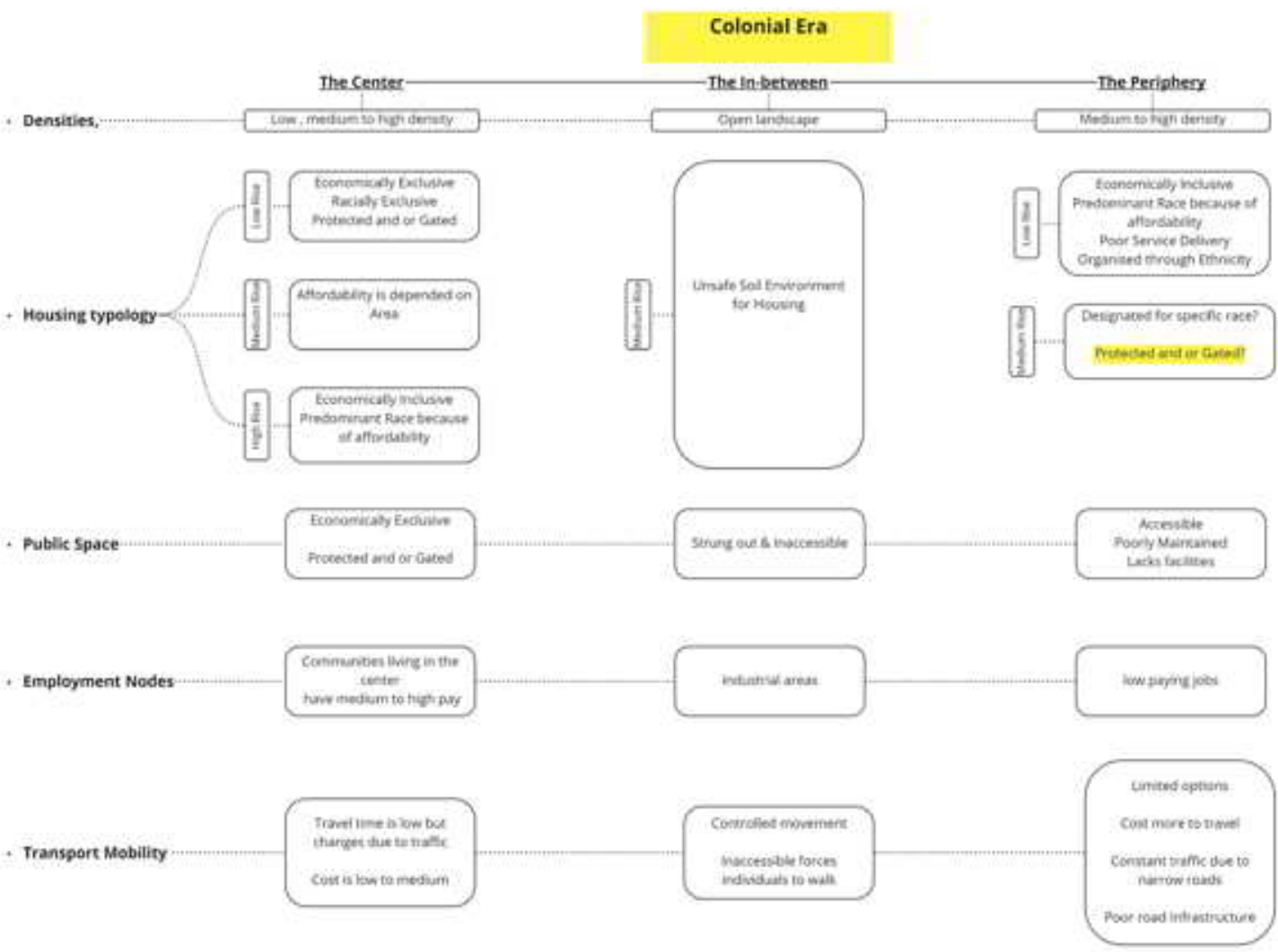

Fig. 3.1 Analytical research of Johannesburg during apartheid (author, 2021) 


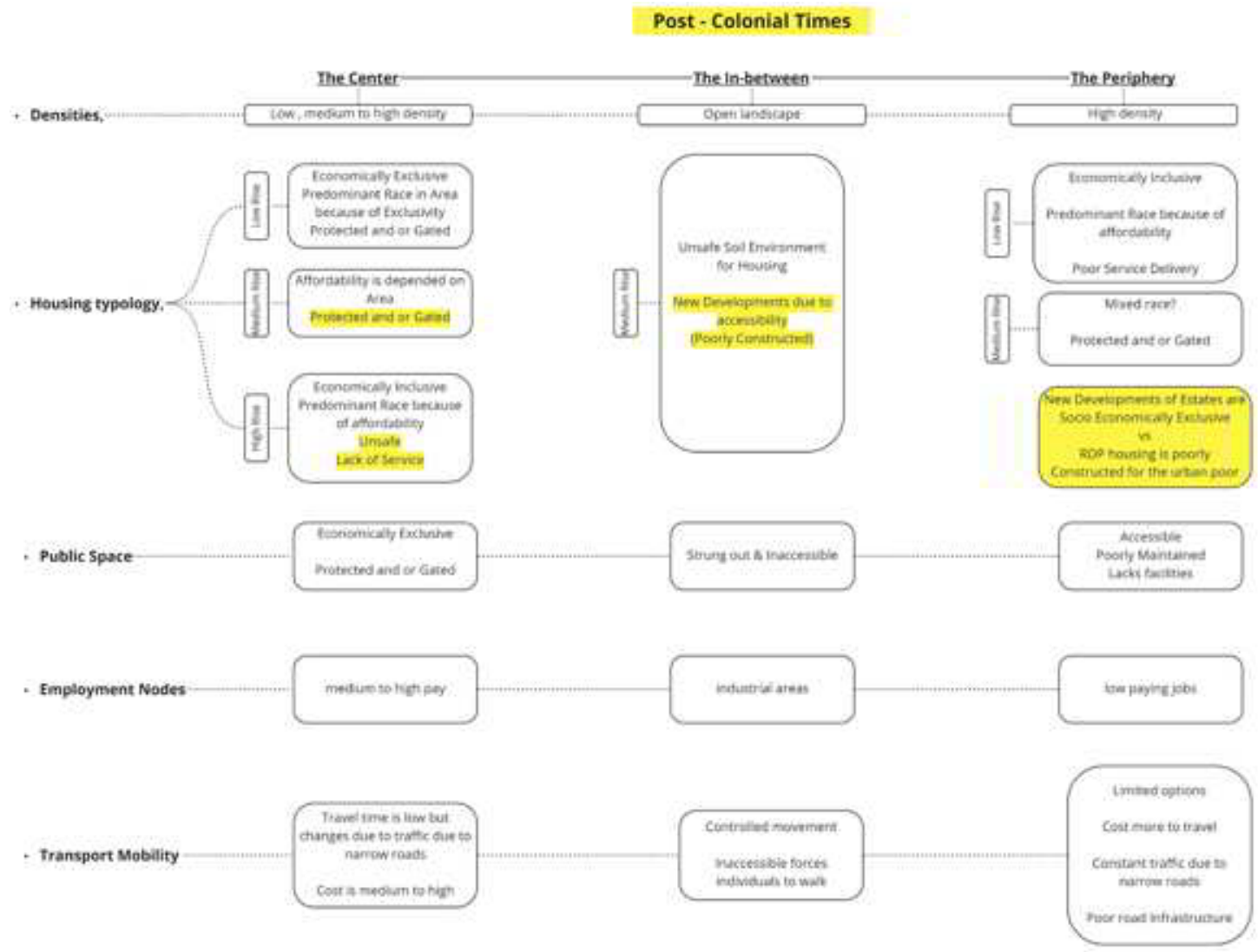

Fig. 3.2 Analytical research of Johannesburg during apartheid (author 2021)

\section{COLLECTING, ANALYSING AND \\ INTERPRETING DATA ON URBAN FORM}

Several researchers have developed tools to and employment. Understand the personal exmeasure fragmentation using data. Figure 4 periences from the centre, the in-between and shows formulas used by researchers to calcu- the periphery. Observing, experiencing and unlate distance between work and living, density derstanding different ways of living, working (population growth), infrastructural develop- and playing within the three nodes will reveal ment in proximity to places of learning, living the immediate realities. 


\section{FRAGMENTATION AND INEQUALITY}

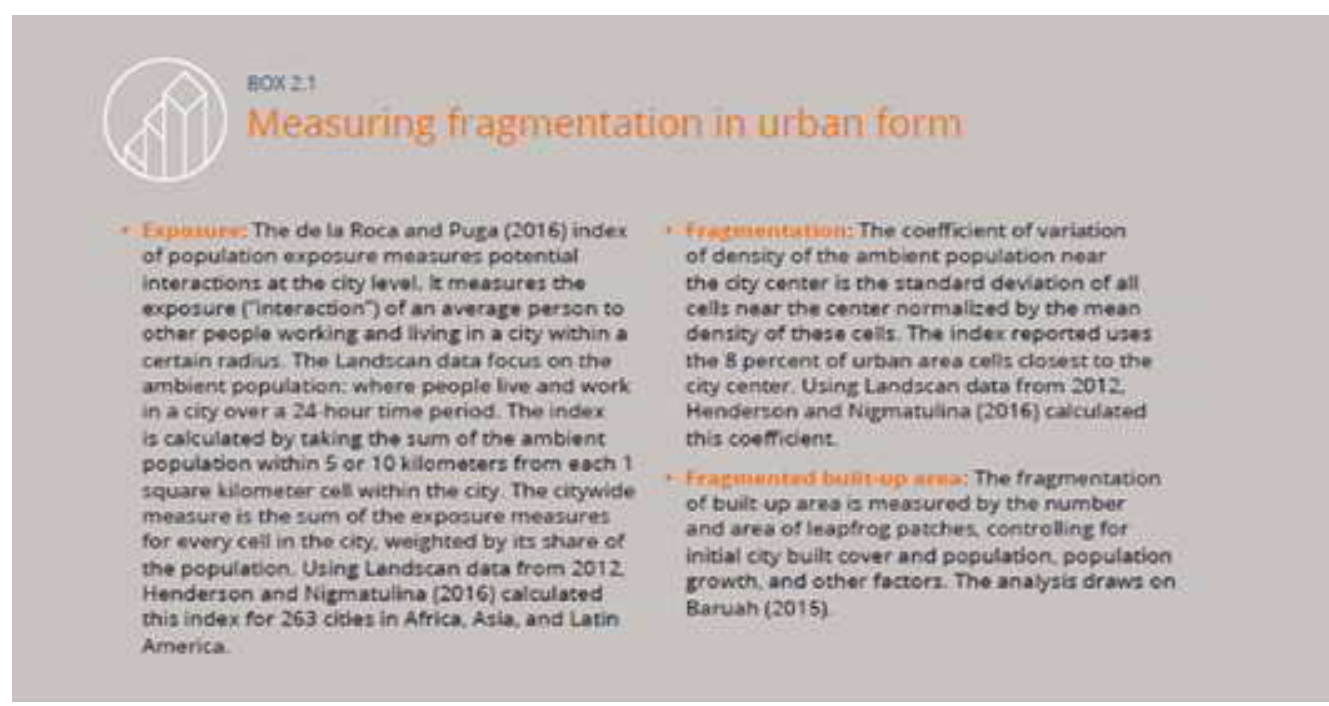

VS

\section{DEFRAGMENTATION AND INCLUSIVE}

\section{URBANISM}

Foverst

Three aspects of buing connected

Scale

Potential for interaction
Distance

Contiguiby of builoup area
Time

Infrastructure to mpport interactions

Fig. 5. Aspects of being connected. (Lall, Henderson and Venables 2017)

\section{KNOWLEDGE ON SPATIAL DEFRAGMENTATION}

Knowledge and literature on defragmentation is limited as the practice of it. It can be closely related to integration and inclusive however, it does not explain the process defragmentation. In order to integrate spatial fragments towards an inclusive environment, initial plans should be to defragment the structurally restrictive systems and physical forms that perpetuate pervasive living environments that create unequal societies. Spatial Defragmentation can be characterised as a process of restructuring, reorganising and reshaping spatial fragments in 
order to provide inclusive public space, equitable living, learning and working spaces in close proximity to one another to reduce travel time and cost. The process removes physical barriers that discourage socio-economic and cultural inclusivity and exchange between different race, income and ethnic groups. The process and steps of defragmentation will be guided by understanding the characteristics of fragmentation at various urban scales; the centre, the in-between and the periphery of the three cities.

\section{CONCLUSION}

From observation, the paper concludes that socio-economic inequality is directly proportional to spatial inequality. Living on the margins far from economic nodes perpetuates a culture

\section{LIST OF FIGURES}

Figure 1.1 Johannesburg Spatial Segregation, archive.unu.edu. [O]. Available from:https://za.pinterest.com/ pin/535154368213004974/ [Accessed 18/05/2020].

Figure 1.2 Badawy, A., Abdel-Salam, H \& Ayad, H. 2018. Historical spatial segregation in Cairo. [O]. Available from: https:// theconversation.com/egypt-isbuilding-a-new-capital-city-fromscratch-heres-how-to-avoid-inequalityand-segregation-103402 [Accessed 18/05/2020]. of exclusion and inequality. The effects of fragmented urban morphology and social segregation so far is as fragmented, as the discourse. Spatial and built environment agents and stakeholders such as the private sector, individuals and spatial practitioners should adopt inclusive urbanism policies in order to address the fragmentation in urban form. Equity and equality may be achieved by restructuring space in cities through investigation of scale, distance and time. It concludes that in order to provide inclusive urban form, a spatial defragmentation process should be implemented. It can be adopted as a conceptual urban design framework, guideline, a policy, and a design toolkit aimed at spatial fragments around housing, economic nodes, transport mobility and public space in the center, the in-between and the periphery.

Figure 1.3 Ajibade, I. 2013. Map of Lagos showing income levels. Research Gate Net. [O]. Available from: https://www.researchgate. net/figure/Map-of-Lagos-showingincome-levels_fig1_258111513 [Accessed 18/05/2020].

Figure 2. Author, View of Soweto from the mine dump. 2021

Figure 3. Author, View of Soweto from the mine dump. 2021

Figure 3.1 Author, Analysis diagram- colonial times. 2021 
Figure 3.2 Author, Analysis diagram- post colonial times. 1. 2021

Figure 4 Lall, S., Henderson, J \& Venables, A. 2017. Measuring fragmentation in urban form

Figure 5 Lall, S., Henderson, J \& Venables, A. 2017. Aspects of being connected

\section{REFERENCES}

African Development Bank Group. 2018. Nigeria - Eko Atlantic City Development, Lagos, Nigeria - Shoreline Protection, Land Reclamation and City Masterplanning - ESIA Summary. [O]. Available from: https://www.afdb.org/en/documents/ document/nigeria-eko-atlantic-citydevelopment-lagos-nigeria-shorelineprotection-land-reclamation-and-citymasterplanning-esia-summary-106865. Accessed 16/07/2020.

Angel, Shlomo. 2018. New Urban PeripheriesEssays_Urban Age. LSE cities, p1. [O]. Available from: https://urbanage.lsecities. net/essays/new-urban-peripheries. Accessed 5/06/2020.

Badawy, Aya, Abdel-Salam, Hassan and Ayad, Hany. 2015. Investigating the impact of urban planning policies on urban division in Cairo, Egypt: The case of El-Maadi and Dar El-Salam. [O]. Available from: http:// www.elsvier.com/locate/aej, [Accessed 13/05/2020].
Baruah, Neeraj, Henderson, J Vernon and Peng, Cong. 2017. Colonial Legacies: Shaping African Cities. [O]. Available: http:// eprints.lse.ac.uk/86574/1/sercdp0226. pdf. Accessed: 13/05/2020.

Bremner, Lindsay. 1998-2008. Writing the City into Being: Essays on Johannesburg. Johannesburg: Fouthwall

Chipkin, Clive. 2008. Johannesburg Transition: Architecture \& Society from the 1950. Johannesburg: STE Publishers.

Demissie, Fassil. 2012. Colonial Architecture and Urbanism in Africa, Intertwined and Contested Histories. London: Routledge.

Fang, Chuanglin and Yu, Danlin. 2017. Urban agglomeration: An evolving concept of an emerging phenomenon. [O]. Available from: http://www.elsevier.com/locate/ landurbanplan. Accessed 13/05/2020.

Graafland, Arie. 2012. African Perspectives- South Africa. City, Society, Space, Literature and Architecture. Rotterdam: 010 Publishers

Haylett, Chris. 2003. Culture, Class and Urban Policy: Reconsidering Equality. 35:5573. [O]. Available from:https://doi. org/10.1111/1467-8330.00302. Accessed $17 / 06 / 2020$.

Jimenez, Lai. 2012. Citizens of No Place: An Architectural Graphic Novel. New York: Princeton Architectural Press. 
Khalifa, Marwa, Van Nes, Akkelies, Salheen, Mohamed and Hamhaber, Johannes. 2014. Understanding urban segregation in Cairo: The social and spatial logic of a fragmented city. [O]. Available from: http://www.researchgate.net/ publication/276285052. Accessed 20/05/2020.

Kreutzfeldt, Dorothee and Malcomess, Bettina. 2013. Johannesburg Not No Place. Johannesburg. Jacana Press.

Lall, Somik, Henderson, J Vernon and Venables, Anthony. 2017. African Cities: Opening Doors to the world. World Bank, Washington, DC. [O]. Available from: http://elibrary.worldbank.org/doi/ book/10.1596/978-1-4648-1044-2. Accessed 20/05/2020.

Lepofsky, Jonathan and Fraser, James. 2003. Building Community Citizens: Claiming the Right to Place-Making in the City: 127142. [O]. Available from: http://www. researchgate.net/publication. Accessed 26/05/2020.

Mahmoud, Randa A and Rashed, R. 2016. New Cairo's Urban Paradox: All-Inclusive Urbanism vs. Social Exclusion. SBE16Cairo. [O]. Available from:https://www. researchgate.net/publication/333798565. Accessed 18/07/2020.

Mbembe, Achille and Nutall, Sarah. 2007. The Elusive Metropolis. Johannesburg: Wits University Press.
Moreno, Eduardo. 2018. Urbanisation TrendsEssays_Urban Age. LSE cities, p1. [O]. Available from:https://urbanage.lsecities. net/essays/urbanisation-trends. Accessed on $20 / 06 / 2020$.

Morphet, Tony. 1998. "Personal Traits: The work of Eaton and Bierman in Durban". Blank Architecture, Apartheid and After, editado por Judin, H. \& Vladislavic, I. Rotterdam: NAi Publishers 5:148-161.

Mushongera, Darlington and Gotz, Gauteng. 2015. Gauteng city-region observatory quality of life survey: Changing social fabrication-Inequality. [O]. Available: http://www.gcro.ac.za. Accessed 15/05/2020.

Nnamdi, Elleh. 1997. African Architecture: evolution and transformation. New York: The Mcgraw - Hill Companies.

Obiadi, Bons and Nzewi, Ugochukwu Nzewi. 2018. "The Creation of Abuja, Nigeria Slums: A case of Abuja, Nigeria's failed Master Plan Implementation". [O]. Journal of Trend in Scientific Research and Development (IJTSRD). Available: www.ijtsrd.com. International ISSN, 2:2456-6470.

Pieterse, Edgar. 2009. African Cities: Grasping the unknowable. Inaugural lecture, 1. [O]. Available from: https://www.alnap.org/ system/files/content/resource/files/main/ grasping-the-unknowable-26-august-09. pdf. Accessed June 2020. 
Sands, Melissa L. 2017. Exposure to inequality

affects support for redistribution.

Proceedings of the National Academy

of Sciences, 114(4), 663-668. [O].

Available:http://www.pnas.org/cgi/

doi/10.1073/pnas.1615010113 [Accessed 20/06/2020].

Tebogo Ramatlo is an architect, maker, performing arts choreographer and lecturer at Tshwane University of Technology. He established himself as an architect and teacher who integrates thinking and making in his practice since his master's dissertation, uses large scale model building and stop frame animation to narrate an urban future in which migrant women with children help build the city in which they seek shelter. In 2018, he collaborated in the Time, Space Existence Exhibition at the Venice Biennale with Nadia Tromp of Ntsika Architects where they built an installation raising awareness about refugees from Africa
Watson, Vanessa. 2013. "African urban fantasies: dreams or nightmares?" International Institute for Environment and Development (IIED). [O], 26(1): 215-231. Available from: www.sagepublications.com. Accessed 18/07/2020.

and Europe as part of a global architectural discourse. He frequently collaborates with 26'10 south Architects on projects that focus on the transformation of South Africa's built landscape. Since then he has travelled extensively to Berlin, Turkey, Peru, São Paulo and Los Angeles where he has given lectures and collaborative workshops on migration, informality, sustainability and homelessness in cities. He is currently a Doctoral Candidate in architecture at TUT and his thesis focuses on defragmentation of colonial cities in Africa from the centre, the in-between and the periphery.

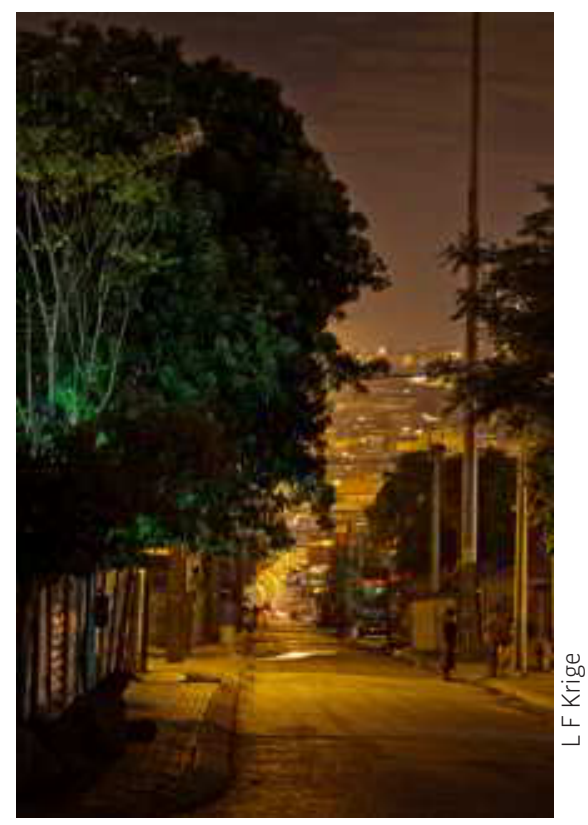

